\title{
FAST RESPONSE GARDA AMPUH DALAM PENANGANAN ANAK MUDA PUTUS SEKOLAH DI BANYUWANGI
}

\author{
Ilham Nur Kholiq \\ Institut Agama Islam Darussalam Blokagung Banyuwangi \\ Email : choliq89@gmail.com
}

\begin{abstract}
The achievements and innovations developed by Banyuwangi District turned out to have many problems in the midst of the community, such as poverty, education (out of school children) who needed good handling. Based on observations and information obtained by researchers there are 10 sub-districts in Banyuwangi District, where the highest number of school dropouts is Rogojampi, Glagah, Tegaldlimo, Banyuwangi City. Gambiran, Kalipuro, Muncar, Kalibaru, Wongsorejo, and Singojuruh. The method used in this study is a qualitative method with descriptive analysis techniques. The data collection techniques using observation, interviews, and documentation. And the data sources are children who experience school dropouts, the Education Office, Tegadlimo UPTD and archives of school dropouts in Kecamatan Teglimlimo. The results of this study indicate, that the factors of school dropouts in Tegadlimo sub-district, Kalipait Village, Kendalrejo and Purwoagung are economic factors, leaving their parents to leave as migrant workers or die, access roads, juvenile delinquency and the environment. Whereas the government's way of dealing with school dropouts is by providing pocket money, smart Banyuwangi transport money, effective garda savings, being included in the package A, B and C equality program, KIP (Kartu Indonesia Pintar) program and SAS Program (Siswa asuh Sebaya).
\end{abstract}

Keywords: Effective Guards, Dropout Children

\begin{abstract}
Abstrak
Prestasi dan inovasi yang dikembangkan kabupaten Banyuwangi ternyata banyak menyimpan persoalan ditengah tengah masyarakat seperti kemiskinan, pendidikan (anak anak putus sekolah) yang membutuhkan penangan secara baik. Berdasarkan observasi dan informasi yang diperoleh peneliti ada 10 kecamatan di kabupaten Banyuwangi yang jumlah anak putus sekolah paling banyak seperti Rogojampi, Glagah, Tegaldlimo, Banyuwangi Kota. Gambiran, Kalipuro, Muncar, Kalibaru, Wongsorejo, danSingojuruh. Metode yang digunakan dalam penelitian ini adalah metode kualitatif dengan teknik analisis deskriptif. Adapun teknik pengumpulan data dengan menggunakan observasi, wawancara, dan dokumentasi. Dan sumber datanya adalah anak yang mengalami putus sekolah, dinas Pendidikan, UPTD Pendidikan Tegadlimo dan arsip arsip anak putus sekolah dikecamatan Tegaldlimo. Hasil penelitian ini menunjukkan, Bahwa faktor faktor anak putus sekolah di kecamatan Tegadlimo Desa Kalipait, Kendalrejo dan Purwoagung yaitu faktor ekonomi, ditinggal orang tuanya pergi jadi TKI atau meninggal dunia, akses jalan, kenakalan remaja dan lingkungan. Sedangkan cara pemerintah dalam menangani anak putus sekolah dengan cara memberikan uang saku, uang transport Banyuwangi cerdas, tabungan garda ampuh, diikutkan program kesetaraan paket A, B dan C, program KIP (Kartu Indonesia Pintar) dan Program SAS (Siswa Asuh Sebaya).
\end{abstract}

Kata Kunci : Garda Ampuh, Anak Putus Sekolah 


\section{A. Pendahuluan}

Pendidikan pada hakekatnya merupakan suatu upaya mewariskan nilai, yang akan menjadi penolong dan penentu umat manusia dalam menjalani kehidupan, sekaligus untuk memperbaiki nasib dan peradaban umat manusia. Berdasarkan UU pendidikan Nasional No 20 tahun 2003 pasal 34 ayat (1-3) dinyatakan bahwa; 1) Setiap warga negara yang berusia 6 tahun dapat mengikuti wajib belajar. 2) Pemerintah dan pemerintah daerah menjamin terselenggaranya wajib belajar minimal pada jenjang pendidikan dasar tanpa memungut biaya. 3) Wajib belajar merupakan tanggung jawab negara yang diselenggarakan oleh lembaga pendidikan, pemerintah danmasyarakat.

Dalam undang undang tersebut dinyatakan bahwa konsep pendidikan diklasifikan menjadi tiga hal yaitu formal, informal dan non formal, UU tahun 2003 No. 20 ayat 10 menjelasakan bahwa satuan pendidikan merupakan kelompok layanan pendidikan yang menyelenggarakan pendidikan pada tinggkat formal, informal dan non formal pada setiap jenjang pendidikan. Banyuwangi merupakan kabupaten terluas di Jawa Timur yang berada ujung timur pulau jawa dengan julukan (sunrise of java). Sebagian besar masyarakat Banyuwangi merupakan daerah pertanian sehingga banyak masyarakat yang bekerja di bidang pertanian. Seluruh anggota keluarga ikut berperan aktif dalam mengerjakan pekerjaan di sawah baik laki-laki maupun perempuan dalam memenuhi kebutuhan hidup keluarganya. Untuk memenuhi kebutuhan hidup keluarganya mereka rela untuk meninggalkan pendidikan atau karena iming-iming pekerjaan di kota atau luar negeri. Kerena alasan ekonomi untuk memenuhi kebutuhan keluarganya sehingga tidak bisa mengikuti pendidikan formal yang menurut mereka biaya yang mahal dan tidak ada waktu untuk membantu memenuhi kebutuhan hidup keluarganya. Namun dengan hal tersebut tidak menjadi alasan anak usia sekolah tidak mendapatkan pendidikan karena merekamasih bisa merasakan pendidikan yang murah dan waktu yang tidak terikat, yaitu melalui pendidikan non-formal.

Banyak prestasi yang terus bermunculan yang diperoleh seperti festival budaya, peningkatan taraf hidup, pendidikan dan lain lain. Selain itu juga inovasi dan terobosan banyak dilakukan dengan tujuan untuk kesejahteraan masyarakat. Prestasi dan inovasi yang dikembangkan kabupaten Banyuwangi ternyata banyak 
menyimpan persoalan ditengah tengah masyarakat seperti kemiskinan, permasalahan pendidikan seperti anak anak putus sekolah atau rentan putus sekolah, buta huruf dan permasalahan permasalahan lain mengenai pendidikan yang membutuhkan penangan secara baik dari pemerintah daerah, kecamatan, desa dan kerjasama dari semua pihak masyarakat.

Pada tahun 2014 Bupati Banyuwangi telah mengeluarkan Peraturan Bupati (Perbup) Nomor 4 Tahun 2014 mengenai Gerakan Masyarakat Pemberantasan Tributa dan Pengangkatan Murid Putus Sekolah (Gempita- Perpus) Kabupaten Banyuwangi. Awal mulanya program Gempita-Perpus hanya fokus pada permasalahan buta aksara di Banyuwangi yang angkanya ketika itu tergolong tinggi. Program Gempita-Perpus berhasil menuntaskan puluhan ribu warga buta aksara di seluruh Banyuwangi. Setelah berhasil menuntaskan para buta aksara maka peserta didik wajib untuk mengikuti program setaraan agar tidak kembali menjadi buta aksara.

Gempita-Perpus Sejak tahun 2016 berubah menjadi Garda Ampuh (Gerakan daerah angkat anak muda putus sekolah). Dalam Garda Ampuh ada pengelompokan yang disesuaikan dengan usianya. Usia 6-21 tahun/usia sekolah formal, maka wajib kembali ke sekolah formal. Dan sekolah formal yang menerima anak putus sekolah/DO tidak boleh memungut biaya serupiahpun. Usia diatas 21 tahun diarahkan menjadi peserta didik pusat kegiatan belajar masyarakat (PKBM) dan (Pokjar) kelompok belajar yang menyelenggarakan program kesetaraan. Melalui program Garda Ampuh ini ribuan siswa DO (dropout) dapat kembali bersekolah baik di formal maupun di program pendidikan kesetaraan.

Berdasarkan observasi dan informasi yang diperoleh peneliti ada 10 kecamatan di kabupaten Banyuwangi yang jumlah anak putus sekolah palingbanyak seperti Rogojampi, Glagah, Tegaldlimo, Banyuwangi Kota. Gambiran, Kalipuro, Muncar, Kalibaru, Wongsorejo, dan Singojuruh. Dari beberapa kecamatan tersebut setelah digali informasi tahun pelajaran 2016/2017 ditemukan jumlah 5.243 anak putus sekolah. banyak faktor yang menyebabkan mereka putus sekolah seperti orang tua yang bangkrut, meninggal, PHK orang tua dan lain sebagainya. Hal ini dapat dilihat dari keadaan penduduknnya yang penuh dengan keterbatasan dan keterbelakangan dalam sumber daya manusia, sosial dan 
ekonomi. Berdasarkan permasalahan tersebut di atas serupa dengan kecamatan Tegaldlimo. Berdasarkan hasil observasi sekilas di masyarakat, fakta di lapangan bahwa di Kecamatan Tegaldlimo merupakan tergolong sepuluh kecamatan yang terdapat banyak anak putus sekolah. Faktor penyebab anak putus sekolah disebabkan oleh lingkungan atau keluarga, adapula faktor lain yang mempengaruhi yaitu pekerjaan orang tua tiba-tiba bangkrut dan lain sebagainya. Pada dasarnya masyarakat di Kecamatan Tegaldlimo berprofesi sebagai buruh, kerja serabutan, nelayan dan petani, Akibat tingkat pendidikan orang tua yang relatif rendah maka motivasi dan kesadaran terhadap pendidikan anak otomatis akan rendah pula. Akibat rendahnya tingkat pengalaman orang tua akan pentingnya pendidikan anak sehingga di Kecamatan Tegaldlimo bertambah yang terdapat pada jenjang pendidikan SD, SMP, maupun SMA. Akibat dari putus sekolah tersebut kebanyakan mereka ada yang hanya bekerja di sawah, pengembala kambing, kerja di Bali bahkan ada yang menjadi TKI, fenomena tersebut anak putus sekolah di Kecamatan Tegaldlimo tidak bisa dibiarkan saja, sehingga perlu mendapat perhatian khusus dari semua pihak baik itu masyarakat maupun pemerintah.

Fenomena anak putus sekolah di atas, akhirnya menjadi perhatian pemerintah yang terus berfikir penuh dan berinovasi dengan membuat program cepat tanggap atau fast response yang dikemas dalam Banyuwangi cerdas dengan membuat gebrakan yang disebut dengan garda ampuh (gerakan daerah anak putus sekolah) program ini membantu masyarakat dengan mengentaskan anak putus sekolah, sejak diluncurkannya program tersebut pemerintah sudah mampu mengentaskan anak putus sekolah secara baik. Berdasarkan data pada tahun 2017 program garda ampuh telah mengentaskan anak putus sekolah sekitar 232 anak dengan mengikutkan program pendidikan kesetaraan paket $\mathrm{A}, \mathrm{B}$ dan $\mathrm{C}$, dan kembali ke pindidikan formal dengan melanjutkan ke bangku sekolahnya kembali. Berdasarkan permasalahan di atas, 1) Apa saja faktor faktor anak putus sekolah di kecamatan Tegaldlimo kabupaten Banyuwangi?, 2) Bagaimana strategi fast response garda ampuh dalam penanganan anak putus sekolah di kecamatan Tegaldlimo Kabupaten Banyuwangi? 


\section{B. Tinjauan Teori}

\section{Anak Putus Sekolah / Dropout}

Putus sekolah bukanlah sesuatu yang baru didengar untuk diperbincangkan, akan tetapi persoalan ini sangat urgen untuk dibicarakan pada kalangan akademisi atau kalangan non akademisi lainya.karena persoalan ini bersentuhan langsung dengan kemajuan sebuah negara dan masyarakat. Dalam kamus besar Bahasa Indonesia (2008:1124) adalah siswa yang belum sampai tamat sekolahnya sudah berhenti. Seorang pakar pendidikan Trismansyah mengatakan bahwa anak putus sekolah yaitu anak yang gagal dalam mengikuti program pendidikan sehingga dia harus berhenti sebelum waktunya (Trismansyah, 1998:18). Ali Imron berpendapat dalam bukunya, mengatakan bahwasannya yang dimaksud siswa putus sekolah adalah siswa yang dinyatakan telah keluar dari sekolah yang bersangkutan sebelum waktu yang telah ditentukan atau sebelum dinyatakan lulus dan mendapat ijazah dari sekolah (Ali Imron, 2004:125). Drop out menurut para akademisi atau yang biasa disebut masyarakat luas yaitu putus sekolah adalah berhenti sekolah sebelum waktunya (Marto Hs dan Saidiharjo, 2002:74) menurut pakar pendidikan yang lain putus sekolah merupaka predikat yang diberikan kepada peserta didik yang tidak mampu menyelesaikan suatu jenjang pendidikan, sehingga tidak dapat melanjutkan studinya ke jenjang berikutnya (Gunawan, 2011:91).

Menurut Ahmad (2011:86) seorang pemikir pendidikan bahwa putus sekolah yaitu berhentinya belajar seorang murid baik ditengah tengah tahun ajaran atau pada akhir tahun ajaran karena berbagai alasan tertentu yang mengharuskan atau memaksanya untuk berhenti. Putus sekolah atau drop out merupakan sebuah tindakan yang tidak diharapkan oleh masyarakat atau pemerintah, karena jika hal itu terjadi maka SDM dalam memajukan sebuah peradaban suatu bangsa akan terhambat. Padahal sebuah pendidikan sangatlah penting bagi memajukan peradaban. Seperti ungkapan Krishnamurti ini dikemas Scott Forbes dalam tujuan pendidikan adalah untuk mendidik seluruh aspek yang dimiliki manusia (all part of the person), mendidik manusia sebagai kesatuan yang utuh (the person as the whole), mendidik manusia sebagai bagian dari kesuluruhan (the person within the whole), yaitu sebagai bagian dari masyarakat, komunitas, dan alam semesta (Jejen Musfah, 2012:36). 


\section{Faktor-Faktor Anak Putus Sekolah}

Adapun faktor-faktor penyebab siswa putus sekolah yang diungkapkan oleh Nana Syaodih Sukmadinata (Bagong Suyanto 2010:342) yang menyatakan bahwa sejumlah faktor yang melatarbelakangi mengapa siswa sampai tinggal kelas adalah sebagai berikut;

1. Sistem yang digunakan oleh sekolah tersebut. Biasanya sekolah-sekolah pada umumnya akan menggunakan sistem maju secara berkelanjutan atau maju secara otomatis, namun jika sekolah tersebut menggunakan sistem tidak naik kelas, maka bisa dimungkinkan akan lebih banyak siswa yang putus sekolah akibat malu dikarenakan akan bertemu dengan adik kelasnya di semseter berikutnya.

2. Berhubungan langsung dengan kemampuan dan usaha dari siswa tersebut. Pendapat lain yang dikemukakan oleh Ali Imron (2004: 126) menyebutkan bahwa hal yang menyebabkan siswa bisa putus sekolah adalah sebagaiberikut.

a. Orangtua yang tidak mempunyai biaya untuk sekolah putra/putrinya.

b. Karena sakit yang diderita yang tidak akan tahu kapan sembuhnya.

c. Siswa yang terpaksa untuk bekerja demi menyambung hidup keluarga.

d. Karena di droup-out dari sekolah yang bersangkutan.

e. Faktor yang berasal dari siswa itu sendiri, yaitu keinginan siswa itu sendiri yang ingin putus sekolah atau tidak ingin melanjutkan sekolah ke tingkat berikutnya.

Berdasarkan pendapat para tokoh di atas bahwa faktor anak putus sekolah tidak hanya sekedar ekonomi akan tetapi lingkungan hidup, keluar, masyarakat. Adapun faktor-faktor anak putus sekolah secara terperinci adalah sebagai berikut;

a. Ekonomi

Berbicara tentang kemiskinan penduduk tentu saja tidak terlepas dari pengeluaran rata-rata rumah tangga perbulan. Asumsi ini bila dijelaskan bahwa semakin tinggi rata-rata pengeluaran rumah tangga semakin rendah kemungkinan anak untuk meninggalkan sekolah (semakin tinggi rata-rata konsumsi semakin rendah drop out). besarnya pengeluaran untuk konsumsi memberikan arti bahwa komponen 
pengeluaran konsumsi lebih penting mereflesikan status ekonomi rumah tangga (Mulyanto Sumardi, 1986:74).

Hal selaras juga dikemukakan oleh Gerungan (1988:182) bahwa hubungan orang tua dengan anaknya dalam status sosial-ekonomi serba cukup dan kurang mengalami tekanan-tekanan fundamental seperti dalam memperoleh nafkah hidupnya yang memadai. Orang tuanya dapat mencurahkan perhatian yang lebih mendalam kepada pendidikan anaknya apabila ia tidak disulitkan dengan perkara kebutuhankebutuhan primer kehidupan manusia.

b. Kultur atau Sosial Budaya

Dalam masyarakat tradisional adanya kebiasaan atau tradisi masyarakat yang dapat menghambat pendidikan anak. Tradisi yang paling menonjol yang dapat dikemukakan adalah cara memandang dan memperlakukan anak. Katakan saja untuk anak perempuan diperlakukan seperti barang dagangan, cepat laku lebih baik. Tak heran jika dalam masyarakat pedesaan marak terjadinya pernikahan dini. Sementara untuk anak lelaki dalam kehidupan masyarakat pedesaan dikader atau diajarkan tata cara bertani dan beternak yang baiksebagaipembekalan untuk menghidupi dirinya dan keluarganya kelak ketika ia sudah dewasa.

Setelah mereka dianggap mampu untuk bertani dan beternak dengan baik serta bisa mencari nafkah sendiri, mereka umumnya berorientasi pada pernikahan. Masyarakat kurang memperhatikan tingkat kematangan kepribadian individu atau tingkat kedewasaan saat melangsungkan pernikahan. Umumnya masyarakat pedesaan menikah pada masa pubertas awal dimana pada masa itu seorang anak masih baru pertama mempunyai rasa suka terhadap lawan jenis (Isnantri, A.C. 2008: Online).

c. Broken Home Atau Faktor keluarga

Menurut undang-undang Republik Indonesia nomor 4 tahun 1979, keluarga adalah Keluarga adalah kesatuan masyarakat terkecil yang terdiri dari ayah dan atau ibu dan anak.Keluarga merupakan kelompok 
sosial pertama dalam kehidupan manusia tempat ia belajar dan menyatakan diri sebagai manusia sosial di dalam hubungan interaksi dengan kelompoknya. Dalam hubungan dengan belajar, keluarga mempunyai peran penting. Keadaan keluarga akan sangat menentukan keberhasilan seorang anak dalam proses belajarnya.

\section{Fast Response Garda Ampuh.}

Nama sub ini fast response atau cepat tanggap merupakan program pemerintah sejak 2016 yang dikemas dalam rumah Banyuwangi cerdas, garda ampuh dilauncingkan bertepatan dengan hari pendidikan nasional yaitu 2 Mei. Tugas dari garda ampuh ini untuk menekan pengurangan anak putus sekolah dan anak rentan putus sekolah di kabupaten Banyuwangi, yang kemudian disebut sebagai garda ampuh yaitu gerakan daerah angkat anak putus sekolah. Program ini diluncurkan tujuannya untuk memeratakan pendidikan dalam meningkakan SDM warga yang semakin hari masyarakat berpendapat bahwa pendidikan tidaklah semakin penting. Fast respon garda ampuh merupakan program yang terdapat dalam Banyuwangi cerdas, program ini dimunculkan untuk mewujudkan wajib belajar 12 tahun untuk seluruh lapisan masyarakat dengan pembiayaan secara gratis dari pemerintah untuk bisa sekolah kembali.

Garda Ampuh (Gerakan Daerah Angkat Anak Muda Putus Sekolah) merupakan program lanjutan dari Gempita Perpus (Gerakan Pemberantasan Tributa dan Pengangkatan Murid Putus sekolah) sebagai salah satu upaya Pemerintah Kabupaten Banyuwangi untuk mengentaskan anak usia sekolah yang tidak bersekolah. Pada awal mulanya program ini ditujukan untuk menekan angka putus sekolah di kalangan anak muda usia produktif, akan tetapi sering berjalannya waktu juga mengakomodir usia produktif non usia sekolah. Disamping itu, Pemerintah Kabupaten Banyuwangi juga terus berupaya untuk mendukung program Garda Ampuh melalui menyekolahkan kembali masyarakat usia sekolah yang bebas buta huruf baik di pendidikan formal maupun nonformal, program siswa asuh sebaya (SAS), program keaksaraan usaha mandiri (KUM) untuk masyarakat yang bebas buta aksara di atas usia produktif, program kursus bahasa asing, dan program smart kampong (Pendidikan.Banyuwangikab.go.id)

Dasar hukum program tersebut adalah Peraturan Bupati Banyuwangi Nomor 
4 Tahun 2014 tentang Program Gerakan Masyarakat Pemberantasan Tributa dan Pengangkatan Murid Putus Sekolah (GEMPITA-PERPUS) Kabupaten Banyuwangi. Dalam program garda ampuh tersebut dibentuklah sebuah team yang ditugasi untuk memburu dan menjaring anak putus sekolah mulai di kota, desa dan plosok-plosok perkampungan yang dibantu oleh elmen masyarakat. Program ini selain melacak juga menerima aduan masyarakat apabila ditemukan anak putus sekolah, kemuadian para team diberikan waktu 1 x 24 jam untuk segera menyelesaikan anak putus sekolah yangbersangkutan.

\section{PenelitianTerdahulu}

Dari penelusuran yang dilakukan peneliti, peneliti menemukan beberapa karya ilmiah yang telah lebih dahulu membahas tema yang hampir serupa, yang kemudian dijadikan kajian pustaka dalam penelitian, di antaranya; 1) Strategi Dinas Pendidikan Dalam Meminimalisir Anak Putus Sekolah Di Kota Bitung. Hasil penelitian yang ditulis oleh Morin Benjami, Agustinus Pati, Dan Frans Singkoh dalam karya ilmiyah berbentuk jurnal menunjukkan bahwa strategi Dinas Pendidikan dalam menekan angka anak putus sekolah di Kota Bitung yaitu strategi sudah cukup baik dalam menekan angka anak putus sekolah, antara lain : Kebijakan Pemerintah Daerah dalam menekan angka Anak Putus Sekolah yakni berupa gerakan penuntasan wajib belajar 12 tahun sebagai wujud pemenuhan hak dasar masyarakat sesuai visi dan misi pembangunan Kota Bitung, Pemberian bantuan dana, Pemberian beasiswa pendidikan bagi masyarakat miskin, Program BSM (Bantuan Siswa Miskin), Program PIP (Program Indonesia Pintar), Program MaMa CEPAT (Cerdas Peduli Anak Tidak Sekolah), dan Sosialisasi kepadamasyarakat. 2) Strategi Kebijakan Kota Surabaya Dalam Menangani Anak Putus Sekolah. Hasil Penelitian yang ditulis oleh Murniawati dalam kajian jurnalnya menunjukkan strategi kebijakan pemerintah kota Surabaya dilakukan dengan menggunakan kombinasi strategi ekspansi dan transformasi. Dimana strategi ini memang ditujukan bagi peningkatan status, kapasitas, serta saranasarana yang berdampak mampu memberi sentuhan warna masa depan keorganisasian yang selaras zaman. Dikombinasikan dengan adanya kebutuhan dari organisasi untuk memenuhi tekanan internal dan eksternal yang pada prinsipnya dilakukan demi terjadinya perubahan fundamental. Strategi ekspansi 
berupa kebijakan preventif atau pencegahan anak agar tidak sampai putus sekolah seperti Beasiswa BOPDA, jalur masuk Mitra Warga. Untuk strategi transformasi memberikan fasilitas program non formal seperti PKBM, Kejar Paket. 3) Analisis Peranan Pemerintah Daerah terhadap Anak Putus Sekolah di Kabupaten Wajo. Hasil penelitian yang ditulis oleh Ahmad Fauzi R, Andi Gau Kadir dan Andi Murfhi dalam karya ilmiyah yang berbentuk jurnal menunjukkan bahwa upaya atau peranan pemerintah daerah dalam menekan angka anak putus sekolah di Kabupaten Wajodiantaranya mengeluarkan kebijakan di bidang pendidikan, bantuan dana pendidikan, pemberian beasiswa pendidikan bagi masyarakat miskin, program bantuan siswa miskin (BSM), serta sosialisasi kepada masyarakat. berdasarkan kasus yang ditemukan penulis di lapangan, faktor yang menjadi penyebab anak putus sekolah adalah kurangnya minat anak untuk bersekolah, keadaan keluarga yang tidak harmonis, lemahnya ekonomi keluarga, kondisi lingkungan tempat tinggal anak, pandangan masyarakat akan pendidikan.

Adapun perbedaan dengan sebelumya yaitu penekanan melalui cepat tanggap atau fast Response melalui Program Garda Ampuh yang digalakkan oleh pemerintah daerah untuk mengentaskan anak anak putus sekolah dan dampat besar positif dan negatif dari putus sekolah.

\section{Metode Penelitian}

Adapun jenis penelitian yang digunakan yaitu Kualitatif, sedangkan pendekatannya menggunakan fenomenologis.

\section{Lokasi Penelitian}

Adapaun lokasi penelitian adalah di desa Kendalrejo Dusun Erpact, Desa Kalipait Dusun Kalilaci dan Desa Purwoagung Dusun Soponyono yang berada di Kecamatan Tegaldlimo Kabupaten Banyuwangi.

\section{Teknik Pengumpulan dan Analisis Data}

Adapun teknik pengumpulan data dalam penelitian ini menggunakan Observasi, Interview dan Dokumentasi. Sedagkan analisis data yang digunakan yaitu mencakup data reduction, penyajian data dan verification. 


\section{Hasil}

Dalam pembahasan ini, penulis akan menyampaikan hasil penelitian berdasarkan temuan temuan penelitian di lapangan mengenai faktor anak putus sekolah dan strategi pemerintah dalam menangani melalui garda ampuh. Adapun pembahasannya adalah sebagai berikut;

\section{Faktor faktor Anak Putus Sekolah}

Faktor anak putus sekolah yang ada di kabupaten Banyuwangi khususnya di kecamatan Tegaldlimo berdasarkan sampel tiga desa yaitu Kalipait (Kalilaci), Kendalrejo (Erpach) dan Purwoagung (Soponyono) diantaranya yaitu;

\section{a. FaktorLingkungan}

Lingkungan merupakan penentu dalam setiap melakukan sebuah tindakan atau aktifitas seperti sekolah, apalagi lingkungan keluarga yang sangat mendukung anak anak untuk terus berpendidikan. Berdasarkan penelitian yang ditemukan di kecamatan Tegaldlimo khusunya di desa Kalipait ada beberapa anak yang putus sekolah dikarenakan kurang dukungan dari orang tua dan lingkungan dikarenakan kurangnya dukungan tersebut karena orang tuanya mengajak anaknya untuk bekerja di hutan atau babatan (Jawa) dan biasanya mereka menginap atau bertempat tinggal didekat tempat kerja, selain itu juga ada yang mengajak darung (jawa) mencari kerang atau ikan di pantai. Hal ini pernah diungkapkan oleh SKPD Kaur kesra Desa Kalipait, bahwa masyarakat yang bertempat di pinggir pantai seperti pantai Plengkung atau pinggiran hutan kurang peduli dengan pendidikan dikarenakan sudah nyaman dengan profesinya mencari ikan atau kerang, dan mereka berpendapat bahwa berpendidikan belum tentu mendapatkan pekerjaan yangsesuai.

\section{b. Ditinggal Orang Tua}

Orang tua merupakan salah faktor utama dalam menunjang kesuksesan anak dalam menempuh pendidikan, pada kasus ini penyebab anak putus sekolah di Banyuwangi selatan khususnya di kecamatan Tegaldlimo yaitu ditinggal oleh orangtuanya, berdasarkan penelitian lapangan bersumber pada UPTD Pendidikan Kecamatan Tegaldlimo bahwa faktor ini merupakan faktor utama atau yang paling banyak dijumpai 
ditengah masyarakat, kebanyakan orang tua pergi keluar negeri untuk bekerja ke beberapa negara seperti Malaysia, Taiwan, Singapura, bahkan ada yang sampai di negara Australia, waktu bekerja mereka (orang tua anak putus sekolah) bisa sampai puluhan tahun. Kejadian seperti ini orang tua yang meninggalakan anaknya biasanya menitipakn kepada nenek dan kakeknya, sehingga dengan,dititipkannya tersebut perhatian atau kasih sayang terhadap anak kurang begitu baik.

Selain orang tua yang pergi ke luar negeri, ada beberapa informasi dari lapangan faktor anak putus sekolah ditinggal orang tuanya karena meninggaldunia, sehingga dengan kejadian seperti ini kehidupan seorang anak yang sedang menempuh pendidikan tidak terkendali. Bahkan tidak terselesaikan sekolahnya.

\section{c. Kenakalan Remaja}

Kenakalan remaja biasanya disebabkan karena lingkungan dan pergaulan bersama teman yang kurang baik. Kejadian seperti halnya kejadian yang berada di Banyuwangi khususnya di desa kalipait dusun kutorejo, salah seorang warga yang bernama bapak Toyiban anaknya yang bernama Alfian melakukan kenalakan remaja seperti minum minuman keras dan nongkrong nongkrong dijalan hal ini disebabkan karena pergaulan yang salah, sampai orang tuanya memberikan nasihat untuk anaknya tidak pernah direspon.

\section{d. Faktor Ekonomi}

Perekonomian merupakan bagian penting masyarakat dalam menunjang kehidupan seseorang. Berdasarkan penelitian yang dilakukan penulis. Kabupaten Banyuwangi khususnya kecamatan Tegaldlimo desa Kendalrejo (erpach), Purwoagung (Soponyono) dan Kalipait (Kalilaci) berprofesi sebagai petani, buruh, pekerja srabutan, dan nelayan mencari ikan, kerang istilah lain dharung (jawa). Profesi yang sudah ditekuni sejak bertahun tahun menjadikan sulit untuk ditinggalkan. Biasanya profesi yang ditekuni tersebut berpengahasilan serba pas pasan untuk menghidupi keluarganya, berdasarkan hal tersebut banyak siswa tidak mampu melanjutkan jenjang pendidikan dan memilih membantu pekerjaan orang 
tuanya, ada yang sebagian mencari pekerjaan yang berbeda dengan tujuan bias meringankan perekonomian orang tua. Seperti yang diungkapkan ibu Samun daerah Kalilaci Kutorejo, beliau meminta anaknya yang bernama Wiranto Adi Nugroho untuk menyelesaikan pendidikan pada tingkat SMP yang hampir selesai, akan tetapi anaknya tidak bersedia untuk melanjutkan dengan berdalih bekerja dengan membantu bapak lebih baik. Dikarenakan bekerja dilaut bisa mendapatkan uang.

Selain itu juga. Ada beberapa masyarakat dengan keterbatasan perekonomian mengajak anakya bekerja ke babatan (jawa) hutan untuk bercocok tanam dan mayoritas mereka bertempat tinggal,di hutan dengan mendirikan rumah sederhana gubuk (Jawa), itupun kalau jaraknya jauh dan jarang pulang.

e. Akses Jalan

Akses jalan merupakan permasalahan yang ditemukan oleh peneliti ketika datang ke lokasi, akses jalan yang dimaksud terdapat pada daerah Erpach Desa Kendalrejo, daerah tersebut letaknya berada di Banyuwangi selatan yang berdekatan dengan hutan dan pantai, untuk menuju daerah tersebut melalui dusun Paluagung. Daerah Erpach merupakan daerah sangat jauh dari akses pendidikan bisa mencapai $10 \mathrm{KM}$, sebagian anak anak yang sekolah merasa kesulitan apabila datang musim hujan dan apabila tidak mempunyai kendaraan tidak mau sekolah. Ada sebagian anak sekolah merasa tidak bisa melanjutkan ke sekolah dikarenakan biaya untuk kendaraan tidak cukup.

\section{E. Pembahasan}

\section{Strategi Garda Ampuh Angkat Anak Putus Sekolah}

Garda ampuh merupakan singkatan dari (Gerakan Daerah angkat anak putus sekolah) yang tergabung dalam program Banyuwangi cerdas .program ini dimuculkan pada tahun 02 Mei 2016 bertepatan dengan hari pendidikan, Pada awalnya program ini dimunculkan karena pemerintah masih banyak melihat permasalahan sosial dan pendidikan secara krusial ditengah tengah masyarakat pedesaan yang berprofesi sebagai petani, buruh tani, nelayan dan masyarakat 
perkotaan yang berprofesi buruh penghasilan rendah atau pengangguran, yang berakibat komunikasi dan informasi masyarakat terbatas. Melihat permasalahan permasalahan tersebut pemerintah terus berinovasi untuk memajukan masyarakat dengan program Banyuwangi Cerdas lewat garda ampuh.

Berdasarkan Instruksi Presiden Nomor 5 Tahun 2006 tentang Gerakan Nasional Percepatan Penuntasan Wajib Belajar. Maka Pendidikan Dasar Sembilan Tahun dan Pemberantasan Buta Aksara (GNPPWB/PBA) yang telah ditindaklanjuti dengan Peraturan Bupati Banyuwangi Nomor 4 Tahun 2014 tentang Program Gerakan Masyarakat Pemberantasan Tributa dan Pengangkatan Murid Putus Sekolah (GEMPITA-PERPUS) terus dilaksanakan. Dengan Peraturan Bupati itu, diharapkan semua warga masyarakat dan stakeholder, mulai dari Kepala Dinas Pendidikan, Camat, Kepala Desa/Kepala Kelurahan dan perangkatnya, serta Kepala UPTD Pendidikan, Pengawas TK/SD dan Penilik berpartisipasi aktif untuk mewujudkan Banyuwangi bebas dari buta aksara.

Dengan banyaknya masyarakat yang sudah terentaskan dari buta aksara maka tahapan selanjutnya adalah memberikan pelayanan pendidikan, untuk usia sekolah dianjurkan ke sekolah formal. Sedangkan yang melebihi usia sekolah akan dilayani dengan pendidikan kesetaraan Paket A setara SD/MI, Paket B setara SMP/MTs dan Paket C setara SMA/MA/SMK, sehingga IPM Kab. Banyuwangi bisa lebih baik. Program garda ampuh mempunyai tujuan tujuan dengan memberikan pelayanan pendidikan secara optimal kepada masyarakat khususnya anak anak yang putus sekolah, selain itu juga pendidikan lanjutan pasca bebas buta huruf aksara juga ditekan dan peningkatan IPM (Indeks Pembangunan Manusia) masyarakat Banyuwangi bisa lebih baik.

Sasaran program garda ampuh ditekankan pada anak anak putus sekolah yang masih kategori usia sekolah produktif dengan memprioritaskan pada umur 6 tahun sampai 21 tahun, masyarakat yang mengikuti kegiatan pemberantasan buta huruf, anak sekolah yang sudah tidak mampu lagi secara ekonomi, anak yatim, anak berkebutuhan khusus dan masyarakat secara umum yang belum mengenyam pendidikan dasar dan menengah. Sedangkan team pelaksana program garda ampuh diantarnya sekolah sekolah formal, pusat kegiatan belajar masyarakat (PKBM) untuk program kesetaraan atau kejar paket, lembaga 
kursusan dan pelatihan (LKP), program pemdidikan kecakapan keluarga atau yang lebih dikenal dengan sebuan (PKK) dan pendidikan kecakapan wirausaha (PKW), selain itu juga ada kelompok kelompok belajar yang berafiliasi yang diselenggarakan di desa desa smart kampung.

Setelah dilakukannya atau penentuan lembaga lembaga yang bekerja sama dengan garda ampuh untuk memberantas anak putus sekolah dan buta aksara, selanjutnya dilakukan sosialisasi kepada masyarakat yang melibatkan UPTD Pendidikan setiap kecamatan, kecamatan kecamatan terkait, desa desa smatr kampung, bahkan dipengajian pengajian kegiatan keumatan juga termasuk tempat sosialisasi program garda ampuh dan sekolah sekolah formal. Bentuk sosialisasi yang dilakukan pemerintah tidak hanya terjun langsung akan tetapi juga membuat pamflet atau iklan iklan untuk mempermudah masyarakat dalam mengetahui program garda ampuh selain itu juga dengan sosialiasi dalam bentuk iklan dan sosmed bertujuan agar masyarakat merespon secara cepat dan bisa daftar secara mandiri ke dinas pendidikan (pendidikan.Banyuwangikab.go.id).

Setalah dilakukan sosialisasi oleh pihak dinas pendidikan kabupaten kebeberapa tempat, tindakkan selanjutnya yaitu membentuk team untuk melakukan pencarian atau pendataan anak putus sekolah, data yang masuk harus lengkap by name by addres, setelah itu peserta bisa melakukan pendataan atau pendaftaran melalui desa yang dibantu oleh SKPD, atau peserta dibantu sama pihak sekolah yang menjadi tempat belajar dan bisa juga melalui on line dengan mengunjungi (http://pendidikan.Banyuwangikab.go.id) dengan membawa bukti atau surat keterangan dari Desa yang bersangkutan. Adapun tindakan dan strategi program garda ampuh dalam mengatasi anak putus sekolah adalah sebagai berikut;

\section{Pemberian Uang Saku dan uang Transport Banyuwangi Cerdas}

Pada tahap ini para peserta garda ampuh anak putus sekolah dan rentan putus sekolah (siswa miskin) diberikan uang saku dan uang transport setiap hari (teknis awal) bisa juga perminggu dan diambil di sekolah masingmasing dengan berkonsultasi pada guru yang berwenang, untuk SD/MI (sekolah dasar/ madrasah ibtidaiyah) diberikan sebesar Rp.5000, sedangkan tingkat SLTP sebesar Rp. 10000 dan SLTA sebesar Rp.15000. 
Uang saku dan uang transport yang diberikan kepada siswa bisa digunakan untuk keperluan mereka selama ada di sekolah dan bisa juga di tabung untuk keperluan jangka panjang. Untuk uang saku dan uang transport garda ampuh (gerakan daerah angkat anak putus sekolah) hanya difokuskan pada empat kecamatan yaitu Wongsorejo, Kalipuro, Muncar dan Tegadlimo (obyek penelitian).

\section{Tabungan GardaAmpuh.}

Tabungan garda ampuh diberikan kepada siswa (SD/MI, SMP/MTs, SMA/MA/SMK dan SLB) yang rentan putus sekolah, tujuannya adalah untuk antisipasi kebutuhan-kebutuhan pelajar di luar biaya pendidikan yang sudah gratis. Misalnya beli sepatu dan tas. Makanya diberi tabungan per anak Rp 1 juta. Program ini merupakan inovasi dalam Banyuwangi cerdas dan baru dilaunchingkan pada awal tahun 2018. Sedangkan pendaftarannya melalui sekolah atau on line (www.Pendidikan.Banyuwangikab.go.id). Setelah pendaftaran online pendaftar mengisi formulir dengan melampirkan proposal yang berisi scan surat permohonan orang tua, surat keterangan dari desa mengetahui camat, surat aktif dari sekolah dan kartu lengkap, setelah itu pihak dinas segera memverikasi data tersebut untuk ditindak lanjuti, berikut gambar pendaftaran tabungan garda ampuh.

Untuk proses pengambilan tabungan garda ampuh bisa dilakukan melalui konsultasi guru untuk memastikan uang tersebut digunakan untuk membeli barang yang menunjang pendidikan mereka. Jadi tidak bisa dibelikan untuk keperluan keperluan lain selain sekolah. Program tabungan garda ampuh ini sangat bermanfaat dan sangat membantu siswa untuk memenuhi kebutuhan sekolah, sehingga kebutuhan yang terpenuhi membuat peserta didik semangat untuk mencari ilmu di bangku sekolah.

\section{Program Kesetaraan Paket A, B \&C}

Adapun tujuan Pendidikan Kesetaraan Paket adalah memperluas akses Pendidikan Dasar 9 tahun melalui jalur Pendidikan Nonformal, Program Paket A dan Paket B. Memperluas akses Pendidikan Menengah melalui jalur Pendidikan Non formal Program Paket, meningkatkan mutu, relevansi dan daya saing Pendidikan Kesetaraan program Paket A, B dan C 
serta menguatkan tata kelola, akuntabilitas dan citra publik terhadap penyelenggaraan dan lulusan Pendidikan Kesetaraan.

Program kesetaraan ini difokuskan untuk mereka Peserta didik diluar usia produktif pendidikan usia 6-21 tahun. Program Garda Ampuh yang memilih meneruskan ke pendidikan non formal/kesetaraan data se-kab Banyuwangi menyebutkan bahwa Paket A, Paket B, dan Paket C terbagi dalam beberapa tingkatan. Program ini dilaksanakan bertujuan untuk membantu masyarakat yang ini punya ijazah. Bahkan ada sebagain masyarakat ikut program kesetaraan melalui garda ampuh dengan tujuan untuk dijadikan syarat agar bisa diterima kerja diluar negeri.

\section{Program KIP (Kartu Indonesia Pintar)}

Selain garda ampuh pemerintah melalui sekolah juga memberlakukan program lain seperti Program KIP. Program ini menjadi bagian terpenting dalam menangani anak putus sekolah dari pemerintah pusat, yang kemudian para siswa direkrut berdasarkan ketentuan yang berlaku. Terkait pencairannya dana diberikan melakui rekening Bank.

\section{Program SAS (Siswa Asuh Sebaya)}

Selain program garda ampuh dan kartu Indonesia pintar (KIP) dalam menangani anak putus sekolah dan anak rentan putus sekolah juga menerapkan Program SAS, program ini merupakan salah satu inovasi pemerintah kabupaten Banyuwangi ini yang dilaunchingkan pada tahun 2011 yang awal mulanya ditujukan untuk siswa miskin atau siswa rentan putus sekolah. Kegiatan ini dilakukan di sekolah masing masing seminggu sekali dengan membawa kotak amal pada setiap kelas dan berinfak secara sukarela 1000, 5000 dan lain sebagainya. Dana yang sudah terhimpun digunakan untuk membantu siswa yangkesulitan mengenai mencukupi alat alat sekolah seperti buku, tas, sepatu bahkan sepeda pancal.

\section{F. Kesimpulan}

Berdasarkan analisis data yang telah peneliti uraikan mengenai anak putus sekolah dan strategi fast respon garda ampuh dalam menangani anak putus sekolah, dapat disimpulkan sebagai berikut; Faktor anak putus sekolah yang ada 
di kabupaten Banyuwangi kecamatan Tegaldlimo desa Kalipait (Kalilaci), Kendalrejo (Erpach) dan Purwoagung (Soponyono) yaitu Ekonomi sehingga anak sekolah yang terkendala oleh ekonomi harus bekerja membantu orang tuanya adakalanya di sawah, mencari ikan di laut dan bekerja di kebun atau babatan (Hutan). Sedangkan faktor lain seperti lingkungan disebabkan kurangnya motivasi atau kepedulian orang tua untuk mendukung anaknya dalam melanjutkan pendidikan dikarenakan pendidikan dianggap tidak terlalu penting apabila sudah bisa mendapatkan uang. Untuk faktor ditinggal orang tua menjadi faktor yang paling banyak dikarenakan ditinggal pergi untuk bekerja ke luar negeri menjadi TKI atau orang tuanya meninggal sehingga dengan kejadian seperti ini anak didik diasuh oleh saudara atau masyarakat sekitar. Selain faktor faktor tersebut juga ada faktor kenakalan remaja dan akses jalan yang menyebabkan anak putus sekolah. Adapun strategi fast respon garda ampuh yang diterapkan pemerintah kabupaten Banyuwangi dalam menangani anak putus sekolah yaitu dengan memberikan bantuan berupa uang saku, uang transport Banyuwangi cerdas, tabungan garda ampuh untuk siswa miskin. Selain dari program yang diikutkan dalam Banyuwangi cerdas pemerintah juga memberikan bantuan dari program KIP (kartu Indonesia Pintar), dan program SAS (Siswa Asuh Sebaya) dalam menangani anak anak yang putus sekolah dan rentan putus sekolah.

\section{Daftar Pustaka}

Ahmad. 2011. Pendidikan Dasar Pada Anak. Jakarta. Trans Info Media. Ali Imron. 2004. Manajemen Peserta Didik Berbasis Sekolah. Malang: Deparmen Pendidikan Nasional.

Ahmad Fauzi R, Andi Gau Kadir dan Andi Murfhi, 2014. Analisis Peranan Pemerintah Daerah terhadap Anak Putus Sekolah di Kabupaten Wajo, Jurnal Ilmu.

Djohani, Rianingsih. 2003. Partisipasi, Pemberdayaan, dan Demokratisasi Komunitas. Bandung. Studio Driya Media.

E.M Sweeting dan Muchlisoh Laporan Teknis No. 18b. 1998. Bebebrapa Penyebab Murid Mengulang Kelas, Putus Sekolah, dan Melanjutkan Sekolah dari SD ke SLTP. Jakarta. Departmen Pendidikan dan Kebudayaan.

Fathurrohman, Muhammad dan Sulistyorini. 2012. Belajar dan Pembelajaran.Yogyakarta. TERAS. 
Gunawan. 2011. Remaja dan Permasalahannya Yogyakarta Hanggar Kreator Jejen MusfahPendidikan Holistic: Pendekatan Lintas Perspektif, Jakarta. Kencana.

Henning F and Columbia R. 1990. Penyelenggaraan dan Penafsiran Hasil-hasil Diskusi Grup Fokus. Majalah Kesehatan Masyarakat Departemen Kesehatan RI.

Irwanto. 1998. Focus Group Discussion (FGD) Sebuah Pengantar Praktis.Jakarta: Pusat Kajian Pembangunan Masyarakat Universitas Katolik Indonesia Atma Jaya.

Lexy J. Moleong. 2007. Metodologi Penelitian Kualiatif. Bandung. Remaja Rosdakarya.

Martono HS dan Saidiharjo. 2002. Geografi dan Kependudukan. Solo. Tiga Serangkai.

Mulyanto Sumardi. 1985. Kemiskinan dan Kebutuhan Pokok. Jakarta. Rajawali

Morin Benjami, Agustinus Pati, Dan Frans Singkoh.2017. Strategi Dinas Pendidikan Dalam Meminimalisir Anak Putus Sekolah Di Kota Bitung. Jurnal Eksekutif, Vol. 1, No. 1. Universitas Sam Ratulangi.

Murniawati. 2015. Strategi Kebijakan Kota Surabaya Dalam Menangani Anak Putus Sekolah. Jurnal, ISSN 2303 - 3411, Vol. 3, No.3. Fakultas Ilmu Sosial dan Politik. Universitas Airlangga.

Noor Rizqa, Faktor Penyebab Anak Putus Sekolah pada Tingkat SMP di Desa Bumi Rejo kecamatan Baradatu kabupaten Way Kanan Tahun 2014 (Jurnal)

Trismansyah. 1998. Anak Putus Sekolah dan Permasalahanya. Jakarta. Percetaka RosdaKarya.

UU RI NO.3 TH. 1997. Undang-Undang Peradilan Anak. Jakarta. Sinar Grafika.

Pemerintahan Volume 4, Nomor 2. 2012. ISSN 1979-5645. Universitas Hasanuddin. 